\title{
Long-term observation of immediately-installed implants after extraction: Retrospective clinical study
}

\author{
Han-Chang Yu' ${ }^{1}$, Dong-Woo Kang ${ }^{1}$, Young-Kyun Kim ${ }^{1,2,3 *}$ \\ ${ }^{1}$ Department of Oral and Maxillofacial Surgery, Section of Dentistry, Seoul National University Bundang Hospital, Seongnam, Korea \\ ${ }^{2}$ Department of Dentistry, School of Dentistry, Seoul National University, Seoul, Korea \\ ${ }^{3}$ Dental Research Institute, Seoul National University, Seoul, Korea
}

The aim of this study was to compare and analyze the survival rate, success rate, and loss of marginal bone of internal and external hexes and presence or absence of microthreads of implant immediately installed after tooth extraction. Forty-four implants were installed in 30 patients, average follow-up period was 80 months, and each product was divided into 3 groups. Group 1 is Osstem TS III implant, Group 2 is Osstem US II implant, and Group 3 is Implantium implant. Panoramic and periapical radiographs were used to measure the marginal bone loss. One implant was removed during the study period, and TS III had a survival rate of $100 \%$ and a success rate of $88 \%$, US II had a survival rate of $100 \%$ and a success rate of $100 \%$, Implantium had a survival rate of $95 \%$ and a success rate of $89 \%$. These results suggest that Osstem and Dentium products show good clinical prognosis when implant is immediately installed after extraction, so it may be a good treatment option in the case of indications.

Key Words: Dental implants, Survival rate, Tooth extraction

(c) This is an open-access article distributed under the terms of the Creative Commons Attribution Non-Commercial License (http://creativecommons.org/licenses/by-nc/4.0) which permits unrestricted noncommercial use, distribution, and reproduction in any medium, provided the original work is properly cited.

\section{서 론}

발치 후 즉시 임플란트 식립은 여러 가지 장점을 가지고 있다. 수술 횟수와 내원 횟수가 줄어들고, 수술 시간을 단축시켜 주며 치은선의 연속성을 유지시켜줄 수 있다. 또한 연조직과 경조직 의 소실을 최소화하면서 전치부에서 심미적인 목적을 달성하기 유리하며, 원래 존재하던 치아를 기준으로 식립하기 때문에 3 차원적으로 이상적인 위치에 식립할 수 있다. 반면 여러 단점들 이나 문제점들 역시 존재하는데 해부학적 주요 구조물을 침범 하거나 초기고정(primary stability)을 얻지 못해 실패할 위험성 이 더 높고, 수술적으로 신경써야 할 부분들이 더 많다. 또한 연
조직, 경조직의 소실을 최소화할 수 있다는 의견들과 달리 오히 려 잔존골의 골대사와 골개조를 활성화시켜 협-설측 치조골의 흡수를 더 진행시킬 수 있고, 변연부 점막의 퇴축 위험이 있다는 의견들도 있다[1,2]. 이러한 합병증들을 방지하기 위해 확실한 증례에서만 발치 후 즉시식립을 시도하는 것이 더 나은 성공률 및 생존율을 얻게 할 수 있다. Al-Sabbagh와 Kutkut [3]에 의하 면 발치 후 즉시식립의 적응증은 구강위생 상태가 좋아야 하며, 인접한 치아들의 상태가 건강하고, 치주조직이 정상적이면서 적절한 골량이 있어야 하며, 발치할 치아들 주변에 급성 염증이 나 종양성 병소들이 없는 경우라고 언급하였다. Buser 등[4] 역 시 발치 후 즉시식립을 하기 위해서는 주변에 $1 \mathrm{~mm}$ 이상의 치

Received February 14, 2019; Revised April 30, 2019; Accepted May 10, 2019

Corresponding author: Young-Kyun Kim, Department of Oral and Maxillofacial Surgery, Section of Dentistry, Seoul National University Bundang Hospital, 82 Gumi-ro 173beon-gil, Bundang-gu, Seongnam 13620, Korea.

Tel: +82-31-787-7541, Fax: +82-31-787-4068, E-mail: kyk0505@snubh.org

Copyright ๑ 2019, Oral Biology Research Institute 
조벽이 존재해야 하며, 두꺼운 바이오타입의 치은을 가져야 하 고 치근단 병소 및 감염이 없어야 한다고 하였다. 발치 후 임플 란트 즉시식립은 1978년 Schulte 등[5]이 증례를 최초로 보고 한 이후로 현재까지 많은 연구가 진행되고 있다. 발치 후 즉시식 립의 경우 식립된 임플란트와 발치와벽 사이의 거리가 중요하 며, Botticelli 등[6]이 jumping distance라는 용어를 사용하였 다. 이는 임플란트 표면에서 수직으로 발치와벽까지의 거리 중 가장 먼 거리를 의미한다. Jumping distance가 $2 \mathrm{~mm}$ 보다 짧 으면 자발적인 골치유 및 골유착이 일어나지만, $2 \mathrm{~mm}$ 보다 길 면 정상적 골치유가 어렵기 때문에 골유도재생술(guided bone regeneration, GBR)이 필요하다고 하였다. Tarnow 등[7]은 골 이식이 없어도 차폐막과 초기봉합이 잘 이루어지는 것과 발치 후 협측골이 온전한 것이 jumping distance를 채우는 데 필요 한 요소라고 하였다.

본 연구에서는 발치 후 즉시식립된 임플란트의 성공률과 생 존율을 임상적으로 평가하고, 보철기능 후 임플란트 주변 골 흡 수량 등에 대하여 알아보고자 한다.

\section{대상 및 방법}

\section{연구 대상}

2005년 1월부터 2011년 12월까지 분당서울대학교병원, 치과 및 구강악안면외과에 내원하여 발치 후 즉시 Osstem사 (Busan, Korea)와 Dentium사(Suwon, Korea)의 임플란트가 식 립된 환자들을 연구대상으로 선정하였다. 30 명의 환자들에게 44 개 임플란트가 식립되었다. 이 중 남자는 17 명, 여자는 13 명 이었고, 환자들의 평균 나이는 55.7세(범위, 21-83세)였다.

\section{연구 방법}

본 후향적 임상연구는 분당서울대학교병원 생명윤리심의위 원회의 승인(IRB no. B-1811/505-113)을 받은 후 시행되었다. 환자의 진료 기록부 및 방사선 촬영 자료(파노라마, 치근단방사 선 사진)를 후향적으로 분석하여 성별, 연령, 식립 위치, 식립된 임플란트의 직경 및 길이, 초기 및 이차 안정도, 골이식 유무, 사 용된 골이식재와 차폐막의 종류, 수술 후 초기 및 지연 합병증, 변연골 소실량, 임플란트 성공률 및 생존율을 조사하였다.

임플란트 식립 후 초기고정과 이차수술 혹은 인상채득 시 이 차고정(secondary stability)은 Osstell mentor (Integration Diagnostics AB, Göteborg, Sweden)를 이용해 측정된 것을 조 사하였다. 총 44 개의 임플란트 중 초기고정은 18 개에서 측정되 었으며 평균치는 66 implant stability quotient (ISQ)였다. 이
차고정은 25 개에서 측정되었으며 평균 67.4 ISQ였다.

제품별 구분은 3 가지로 분류하였다. 1 군은 10 명의 환자들에 게 16개의 Osstem implant TS III SA (Osstem Implant Co.) 가 식립되었다. 남자 9명, 여자 1명이었으며 평균 연령은 62세 였다. 2군은 5명의 환자들에게 9개의 Osstem implant US II (Osstem Implant Co.)가 식립되었다. 남자 3명, 여자 2명이었 으며 평균 연령은 67 세였다. 3 군은 15 명의 환자들에게 19 개의 Implantium implant (Dentium)가 식립되었다. 남자 6명, 여자 9명이었으며 평균 연령은 47세였다. 관찰 기간은 보철 이후부 터 최종 내원 때까지를 분석하였으며, 1 군의 경우 평균 52 개월, 2 군은 103 개월, 3 군은 98 개월이었고 임플란트 식립 시, 보철물 장착 후, 보철물 장착 1 년 후, 최종 관찰 시의 변연골 소실량을 파노라마 혹은 치근단방사선 사진을 이용하여 측정하였다. 식 립된 임플란트의 길이를 참고하여 각 방사선 사진의 확대율을 계산한 후 근심측과 원심측에서의 변연골 흡수량을 측정한 후 평균값을 구하였다.

임플란트의 성공은 Albrektsson 등[8]의 기준을 따라 유동성, 통증, 지각이상, 방사선 투과성 병소, 임플란트 주위염이 존재하 지 않으면서 진행성 골 흡수가 없는 경우(식립 1 년간 $1 \mathrm{~mm}$ 이 하, 이후 연간 $0.2 \mathrm{~mm}$ 이하)로 설정하였으며, 임플란트 생존의 기준은 식립 후 특별한 증상 없이 상부 보철물의 기능이 정상적 으로 이루어지고 있는 경우로 설정하였다.

\section{통계 분석}

3 가지 임플란트 간의 변연골 소실량의 차이는 IBM SPSS Statistics (version 17; SPSS Inc., Chicago, IL, USA)을 이용하여 one-way ANOVA test를 시행하여 검증하였다 $(p<0.05)$.

\section{결 과}

\section{합병증}

발치 후 즉시식립된 44개의 모든 임플란트 증례에서 수술 직 후 창상열개, 출혈, 감염 등과 같은 초기 합병증은 관찰되지 않 았다. 보철물 장착 이후 발생한 지연 합병증은 모두 4 개의 증례 에서 발견되었으며 모두 Implantium을 식립했던 3군이었다. 4 개 중 2 개는 나사풀림, 1 개는 임플란트 주위염, 1 개는 보철물 탈 락이었으며 나사풀림은 각각 보철완료 후 1 년과 4년 2개월 후 발생하였으며, 임플란트 주위염은 보철완료 후 4년 1개월, 보철 물 탈락은 보철완료 후 1년 1개월 후에 발생하였다(Table 1). 
Table 1. Delayed complications after prosthesis delivery

\begin{tabular}{lccll}
\hline & Anterior & Premolar & Molar & \multicolumn{1}{c}{ Total } \\
\hline Maxilla & $0 / 4(0)$ & $2 / 12(16.67)$ & $0 / 3(0)$ & $2 / 19(10.53)$ \\
Mandible & $0 / 5(0)$ & $0 / 9(0)$ & $2 / 11(18.18)$ & $2 / 25(8)$ \\
Total & $0 / 9(0)$ & $2 / 21(9.52)$ & $2 / 14(14.29)$ & $4 / 44(9.09)$ \\
\hline
\end{tabular}

Values are presented as number (\%).

Table 2. Implant distribution and success rate of implants

\begin{tabular}{lcccl}
\hline & Anterior & Premolar & Molar & \multicolumn{1}{c}{ Total } \\
\hline Maxilla & $4 / 4(100)$ & $9 / 12(75)$ & $3 / 3(100)$ & $16 / 19(84.21)$ \\
Mandible & $5 / 5(100)$ & $8 / 9(88.89)$ & $11 / 11(100)$ & $24 / 25(96)$ \\
Total & $9 / 9(100)$ & $17 / 21(80.95)$ & $14 / 14(100)$ & $40 / 44(90.91)$ \\
\hline
\end{tabular}

Values are presented as number (\%).

There was no statistically significant difference between the maxilla and mandible $(p>0.05)$.

\section{골이식 유무에 따른 성공률과 변연골 흡수량}

다양한 차폐막과 골이식재들이 사용되었고 각각의 증례 수가 적어서 통계적 유의성 검증은 시행할 수 없었다. 골이식이 시행 된 경우는 41 개였고 골이식 없이 단순하게 임플란트가 식립된 경우는 3개였다.

\section{임플란트 식립 부위에 따른 성공률과 생존율}

상악에 19개(43.18\%), 하악에 25개(56.82\%)의 임플란트가 식립되었으며, 전치부 9개(20.45\%), 소구치부 21개(47.73\%), 대구치부 14 개(31.82\%)의 분포로 식립되었다. 총 44 개의 임 플란트 중 4 개의 임플란트가 성공 기준을 충족하지 못하였으 며 이중 상악 소구치의 1 개가 제거되었다. 전체적인 성공률은 $90.91 \%$, 생존율은 $97.73 \%$ 였다(Table 2, 3).

\section{식립된 임플란트 종류에 따른 성공률과 생존율}

1 군은 발치 후 Osstem사의 TS III를 즉시식립한 집단으로 16 개의 임플란트가 식립되었고 14 개의 임플란트가 성공하였으며 (87.50\%), 16 개의 임플란트가 생존하였다( $100 \%) .2$ 군은 발치 후 Osstem사의 US II를 즉시식립한 집단으로 총 9개의 임플란 트가 식립되었으며, 9개의 임플란트 모두 성공하였고(100\%), 최종 생존하였다. 3군은 발치 후 Dentium사의 Implantium을 즉시식립한 집단으로 총 19 개의 임플란트가 식립되었으며, 17 개의 임플란트가 성공하였고(89.47\%), 18 개의 임플란트가 생존 하였다(94.74\%) (Table 4).
Table 3. Implant distribution and success rate by group

\begin{tabular}{lcccc}
\hline & Group 1 & Group 2 & Group 3 & Total \\
\hline Anterior & $2 / 2(100)$ & $3 / 3(100)$ & $4 / 4(100)$ & $9 / 9(100)$ \\
Premolar & $7 / 9(77.78)$ & $2 / 2(100)$ & $8 / 10(80)$ & $17 / 21(80.95)$ \\
Molar & $5 / 5(100)$ & $4 / 4(100)$ & $5 / 5(100)$ & $14 / 14(100)$ \\
Total & $14 / 16(87.50)$ & $9 / 9(100)$ & $17 / 19(89.47)$ & $40 / 44(90.91)$ \\
\hline
\end{tabular}

Values are presented as number (\%).

Group 1, Osstem TS III; Group 2, Osstem US II; Group 3, Dentium Implantium.

There was no statistically significant difference between the three groups $(p>0.05)$.

Table 4. Success and survival rates of implants

\begin{tabular}{lcccc}
\hline & Group 1 & Group 2 & Group 3 & Total \\
\hline $\begin{array}{c}\text { Success } \\
\text { rate }\end{array}$ & $14 / 16(87.50)$ & $9 / 9(100)$ & $17 / 19(89.47)$ & $40 / 44(90.91)$ \\
$\begin{array}{c}\text { Survival } \\
\text { rate }\end{array}$ & $16 / 16(100)$ & $9 / 9(100)$ & $18 / 19(94.74)$ & $43 / 44(97.73)$ \\
$\begin{array}{c}\text { Removed } \\
\text { implant }\end{array}$ & 0 & 0 & 1 & 1 \\
\hline
\end{tabular}

Values are presented as number (\%) or number only.

Group 1, Osstem TS III; Group 2, Osstem US II; Group 3, Dentium Implantium.

There was no statistically significant difference between the three groups $(p>0.05)$.

Table 5. Marginal bone loss ( $\mathrm{mm})$

\begin{tabular}{lcccc}
\hline & Group 1 & Group 2 & Group 3 & Total \\
\hline 1-Year after loading & 0.55 & 0.13 & 0.11 & 0.28 \\
Final observation & 0.63 & 0.21 & 0.14 & 0.33 \\
\hline
\end{tabular}

Group 1, Osstem TS III; Group 2, Osstem US II; Group 3, Dentium Implantium.

There was no statistically significant difference between the three groups $(p>0.05)$.

\section{임플란트 변연골 흡수량}

각 임플란트들의 하중부여 1 년 후, 최종 관찰시기의 평균 변 연골 흡수량을 조사하였다. 1군은 하중 1년 후 $0.55 \mathrm{~mm}$, 최종 관찰시기에 $0.63 \mathrm{~mm}$ 의 변연골 흡수를 보였다. 2 군은 하중 1 년 후 $0.13 \mathrm{~mm}$, 최종 관찰시기에 $0.21 \mathrm{~mm}$ 의 변연골 흡수를 보였 으며, 3 군은 하중 1 년 후 $0.11 \mathrm{~mm}$, 최종 관찰시기에 $0.14 \mathrm{~mm}$ 의 변연골 흡수를 보였다. 44 개의 모든 임플란트의 하중 1 년 후 평균 변연골 흡수량은 $0.28 \mathrm{~mm}$ 였으며, 최종 관찰시에는 0.33 $\mathrm{mm}$ 였다. 세 그룹 간 통계분석 결과 통계적으로 유의한 차이는 보이지 않았다 $(p>0.05$; Table 5$)$. 


\section{고 찰}

임플란트의 식립 시기에 대해 다양한 분류가 있지만 대체로 발치 후 즉시 임플란트를 식립하는 경우를 ‘즉시 임플란트’라 고 정의한다. 발치 후 임플란트를 즉시식립하는 경우 환자의 내 원 횟수와 수술 횟수, 전체 치료 기간을 줄일 수 있고, 연조직과 경조직의 소실을 최소화할 수 있으며, 이상적인 위치에 임플란 트 식립이 가능하다는 장점이 있다. 그러나 식립 후 임플란트 상 방의 연조직 치유가 어려우며, 다근치의 경우 치근의 형태적 특 징으로 인해 식립된 임플란트와 발치와 사이의 공간이 많이 생 겨 초기 고정력을 얻기 힘든 경우가 발생할 가능성이 있다[9]. Schwartz-Arad와 Chaushu [10]는 즉시 임플란트에 관한 문헌 고찰 결과 골벽 결손이 없는 발치와에 즉시식립된 임플란트는 93.9\%-100\%의 성공률을 보였으며, 초기 고정력을 확보하기 위 해서 임플란트는 치근단 하방 3-5 mm에 식립되어야 하고 임플 란트의 상방은 치조정에 가깝게 위치되어야 하며(0-3 mm 하 방) 임플란트와 골 사이의 공간에 골 이식은 필요가 없으며, 연 조직의 1차봉합이 추천된다고 하였다. 발치 후 즉시식립된 임플 란트의 성공률과 생존율에 대한 많은 연구결과와 문헌들이 있 다. Mello 등[11]은 30 개의 문헌을 메타분석하여 1,435 명의 환 자에게 즉시식립된 3,049 개의 임플란트를 조사하였다. 여기에 서 지연식립된 임플란트의 경우 생존율은 $98.38 \%$, 발치 후 즉시 식립된 임플란트의 경우 $95.21 \%$ 의 생존율을 보였으며 이는 통 계적으로 유의한 차이를 나타내었다. Ketabi 등[12]은 15 개의 문헌을 메타분석하여 757 명의 구치부에서 즉시식립된 768 개의 임플란트의 기능 후 1 년째 생존율을 조사한 결과 $98 \%$ 라고 보 고하였다. Atieh 등[13]은 9개의 문헌에서 1,013개의 즉시식립 된 임플란트를 메타분석하였고 $99 \%$ 의 생존율을 보고하였다. 본 연구에서 발치 후 즉시식립된 임플란트의 생존율은 $97.73 \%$ 였 으며 이는 기존 문헌들에서 보고된 결과들과 큰 차이를 보이지 않았다. 또한 본 연구에서 발생한 합병증 4 증례는 모두 보철완 료 후 1 년이 지난 뒤 발생한 지연 합병증이었다. 4 개의 증례 모 두 Implantium을 식립한 3군에서 발생하였는데 당시 사용되던 system의 지대주나 나사 등의 제조상 문제점, 보철 치료 시 오 류 등이 원인으로 추정된다.

Tapered 임플란트의 경우 일반적인 straight type의 임플란 트보다 즉시식립 시 협측의 치조골을 조금 더 보존하여 심미적 인 결과를 얻을 수 있으며, 협측골의 천공 위험성을 줄일 수 있 다는 장점을 가진다. 또한 치근단부가 좁고 치관쪽으로 갈수록 넓어지면서, 치조정에서 발치와벽과 임플란트 간의 간격을 줄 이는 데 이점이 있다. 또한 초기 고정력을 얻기 쉬운 장점이 있 다[2,14]. 반면 straight type과 tapered type의 경우 모두 단기 간 관찰결과 초기 고정력에서 큰 차이를 보이지 않았다는 보고
도 있다[15-17].

External connection type 임플란트는 초창기부터 임플란트 에 적용되었던 방식으로 현재까지 수많은 연구결과들이 잘 정 립되어 있다. 또한 internal connection type에 비해 상대적으 로 보철이 편리하며 임플란트의 식립각도에 영향을 덜 받는다. 또한 강한 교합압이 오래 가해지는 부위에서 internal connection type에 비해 abutment sinking 현상이 적게 발생한다. 그 러나 악간 공간이 부족한 위치에서 보철이 어려울 수 있으며, 교 합력에 의한 응력이 나사와 연결부에 집중되어 교합력이 강하 게 작용하면 external hexagon의 경우 미세움직임을 허용하게 되어 연결부의 안정이 떨어지게 되고 나사풀림이나 피로파절 이 일어날 가능성이 더 높다. 또한 임플란트 고정체와 지대주 연 결부 사이에 존재하는 미세 간극의 하방으로 골흡수가 잘 일어 날 수 있다. 이러한 단점을 보완하기 위해 internal connection type의 임플란트가 개발되었고 external connection type에 비 해 미세 간극을 가리는 효과가 있어 골흡수를 방지할 가능성이 조금 더 높으며, 교합에 의한 응력전달에 유리하고 나사풀림 현 상 등이 적다는 장점이 있다. 그러나 보철 시 식립각도에 영향을 조금 더 받게 되며, 강한 교합압이 작용하는 곳에 식립된 경우 교합력에 의해 abutment가 임플란트의 내부로 강하게 밀착되 는 과정에서 abutment sinking 현상이 발생하기 쉽다[18]. External type과 internal type의 변연골 흡수에 있어서 external connection type이 골흡수가 더 많이 일어나는 것으로 보고되 었지만 Esposito 등[19]의 연구에서는 연결 방식에 따른 골흡수 에는 유의한 차이가 없다고 보고되었다. 본 연구에서는 오히려 external type인 2군 Osstem US II에서 변연골 흡수량이 가장 적게 나타났으나 통계적으로 유의성 있는 차이는 없었다.

$\mathrm{Niu}$ 등[20]의 메타분석 연구에 따르면 implant neck 부위의 microthread 디자인은 임플란트의 변연골 소실량을 줄이는 데 효과는 있으나 그 양은 매우 적다고 하였다. 또한 Khorsand 등 [21]의 연구에 따르면 상악 전치부에서 발치 후 즉시식립된 임 플란트에서 microthread 디자인이 변연골 소실량을 줄이는 데 효과가 없다고 하였다. 본 연구에서는 1 군과 3 군의 비교 시 microthread 디자인을 적용한 3군의 변연골 소실량이 더 적었지 만 통계적으로 유의성 있는 차이는 없었다.

본 연구에서 구강 내에 생존했으나 성공률 기준에 부합하지 못한 임플란트는 총 3 개(상악 2개, 하악1개, 소구치)였으며, 골 이식 여부, 임플란트 종류와는 큰 연관성이 없었다. 다만 한 환 자는 10년 이상 심한 이악물기 습관이 있는 환자로, 초진 시 전 반적인 치아의 심한 교모를 확인할 수 있었으며, 다른 환자는 과 거 상악동 수술을 받았으며, 하루 1 갑 이상의 흡연을 하며 구강 위생 관리가 잘 되지 않는 환자였다. 또 다른 환자는 수술 시 식 립 부위의 골열개가 확인되어 $\mathrm{GBR}$ 을 시행하였으나, 의도대로 
골재생이 잘 되지 않은 것으로 생각한다. 실패하여 제거된 임플 란트는 1 증례였는데 48세 남자 환자에서 \#24부위 발치 후 Implantium 제품을 즉시식립한 경우였다. 이 환자는 하루 1갑 이 상의 흡연을 하고 있으며 직업이 의사로 몹시 바쁜 생활을 하면 서 구강위생 관리 및 경과관찰이 잘 안되는 환자였다. 식립 1 주 일 후 수술 부위 봉합사를 제거하고 내원하지 않다가 1년 후 임 플란트가 제거된 상태로 내원하였다.

본 연구의 한계점은 후향적 연구로 인해 각 그룹 간의 증례 수 가 불규칙적이고, 총 증례 수 또한 적어 통계적 검증에 문제가 있었으며 유의미한 결론을 도출하기에 어려움이 있다. 또한 임 플란트 식립 시 사용된 다양한 골이식재와 차폐막, 다양한 폭경 과 길이의 임플란트 사용 등의 수많은 변수들이 있기 때문에 변 연골 소실의 그룹 간 차이를 비교하기에 무리가 있다. 또한 임플 란트 식립 시 초기고정 및 이차고정 측정도 모든 증례들에서 이 루어지지 않아 정확한 확인이 어렵다는 것도 아쉬운 점이다

본 연구의 제한된 조건에서, 발치 후 즉시 임플란트를 식립하 는 경우 Osstem사 및 Dentium사의 임플란트 모두 임상적으로 우수한 예후를 보여주어 적응증에 해당하는 증례에서 발치 후 즉시 임플란트 식립은 좋은 치료 방안이 될 수 있다.

\section{CONFLICTS OF INTEREST}

The authors declare that they have no competing interests.

\section{ORCID}

\author{
Han-Chang Yu \\ https://orcid.org/0000-0001-9050-025X \\ Dong-Woo Kang \\ https://orcid.org/0000-0002-0118-0053 \\ Young-Kyun Kim \\ https://orcid.org/0000-0002-7268-3870
}

\section{REFERENCES}

1. Oh SY. Clinical consideration of immediate implant placement. J Korean Dent Assoc 2017;55:716-724.

2. Kim YK. Bone graft in immediate implantation after anterior tooth extraction. J Korean Dent Assoc 2017;55:725732.

3. Al-Sabbagh M, Kutkut A. Immediate implant placement: surgical techniques for prevention and management of complications. Dent Clin North Am 2015;59:73-95. doi: 10.1016/j.cden.2014.09.004.

4. Buser D, Chappuis V, Belser UC, Chen S. Implant placement post extraction in esthetic single tooth sites: when immediate, when early, when late? Periodontol 2000 2017;73:84-102. doi: 10.1111/prd.12170.

5. Schulte W, Kleineikenscheidt H, Lindner K, Schareyka R. The Tübingen immediate implant in clinical studies. Dtsch Zahnarztl Z 1978;33:348-359.

6. Botticelli D, Berglundh T, Lindhe J. Hard-tissue alterations following immediate implant placement in extraction sites. J Clin Periodontol 2004;31:820-828. doi: 10.1111/j.1600051X.2004.00565.x.

7. Tarnow DP, Chu SJ, Salama MA, Stappert CF, Salama H, Garber DA, Sarnachiaro GO, Sarnachiaro E, Gotta SL, Saito H. Flapless postextraction socket implant placement in the esthetic zone: part 1. The effect of bone grafting and/or provisional restoration on facial-palatal ridge dimensional change-a retrospective cohort study. Int J Periodontics Restorative Dent 2014;34:323-331. doi: 10.11607/prd.1821.

8. Albrektsson T, Zarb G, Worthington P, Eriksson AR. The long-term efficacy of currently used dental implants: a review and proposed criteria of success. Int J Oral Maxillofac Implants 1986;1:11-25.

9. Lazzara RJ. Immediate implant placement into extraction sites: surgical and restorative advantages. Int J Periodontics Restorative Dent 1989;9:332-343.

10. Schwartz-Arad D, Chaushu G. The ways and wherefores of immediate placement of implants into fresh extraction sites: a literature review. J Periodontol 1997;68:915-923. doi: 10.1902/jop.1997.68.10.915.

11. Mello CC, Lemos CAA, Verri FR, Dos Santos DM, Goiato MC, Pellizzer EP. Immediate implant placement into fresh extraction sockets versus delayed implants into healed sockets: a systematic review and meta-analysis. Int J Oral Maxillofac Surg 2017;46:1162-1177. doi: 10.1016/ j.ijom.2017.03.016.

12. Ketabi M, Deporter D, Atenafu EG. A systematic review of outcomes following immediate molar implant placement based on recently published studies. Clin Implant Dent Relat Res 2016;18:1084-1094. doi: 10.1111/cid.12390.

13. Atieh MA, Payne AG, Duncan WJ, de Silva RK, Cullinan MP. Immediate placement or immediate restoration/loading of single implants for molar tooth replacement: a systematic review and meta-analysis. Int J Oral Maxillofac Implants 2010;25:401-415.

14. Kim HK, Lee EY, Kim JJ. Five-year retrospective radiographic follow-up study of dental implants with sandblasting with large grit, and acid etching-treated surfaces. J Korean Assoc Oral Maxillofac Surg 2015;41:317-321. doi: 10.5125/jkaoms.2015.41.6.317.

15. Lang NP, Tonetti MS, Suvan JE, Pierre Bernard J, Botticelli D, Fourmousis I, Hallund M, Jung R, Laurell L, Salvi GE, Shafer D, Weber HP. Immediate implant placement with transmu- 
cosal healing in areas of aesthetic priority. A multicentre randomized-controlled clinical trial I. Surgical outcomes. Clin Oral Implants Res 2007;18:188-196. doi: 10.1111/ j.1600-0501.2006.01371.x.

16. Araújo MG, Sukekava F, Wennström JL, Lindhe J. Ridge alterations following implant placement in fresh extraction sockets: an experimental study in the dog. J Clin Periodontol 2005;32:645-652. doi: 10.1111/j.1600051X.2005.00726.x.

17. Araújo MG, Lindhe J. Dimensional ridge alterations following tooth extraction. An experimental study in the dog. J Clin Periodontol 2005;32:212-218. doi: 10.1111/j.1600051X.2005.00642.x.

18. Vigolo P, Gracis S, Carboncini F, Mutinelli S. Internal- vs external-connection single implants: a retrospective study in an Italian population treated by certified prosthodontists. Int J Oral Maxillofac Implants 2016;31:1385-1396. doi: $10.11607 /$ jomi.4618.

19. Esposito M, Maghaireh H, Pistilli R, Grusovin MG, Lee ST, Trullenque-Eriksson A, Gualini F. Dental implants with internal versus external connections: 5-year post-loading results from a pragmatic multicenter randomised controlled trial. Eur J Oral Implantol 2016;9 Suppl 1:129-141.

20. Niu W, Wang P, Zhu S, Liu Z, Ji P. Marginal bone loss around dental implants with and without microthreads in the neck: a systematic review and meta-analysis. J Prosthet Dent 2017;117:34-40. doi: 10.1016/j.prosdent. 2016.07.003.

21. Khorsand A, Rasouli-Ghahroudi AA, Naddafpour N, Shayesteh YS, Khojasteh A. Effect of microthread design on marginal bone level around dental implants placed in fresh extraction sockets. Implant Dent 2016;25:90-96. doi: 10.1097/ID.0000000000000350. 